\title{
PROGRAM CAPACITY BUILDING BAGI PRAMUWISATA DI KOTA AMBON, PROVINSI MALUKU
}

\author{
Christian Albert Lewier ${ }^{1 *}$, Rita Fransina Maruanaya ${ }^{2}$, Abraham Soyem ${ }^{3}$ Febrio Liong Titaley ${ }^{4}$ \\ Meytty Jeanly Pattikawa ${ }^{5}$ \\ ${ }^{1}$ Pendidikan Bahasa Inggris, FKIP Universitas Pattimura, lewier_73@yahoo.com \\ ${ }^{2}$ Pendidikan Bahasa Jerman, FKIP Universitas Pattimura, ritamaruanaya@yahoo.co.id \\ ${ }^{3}$ Pendidikan Bahasa Inggris, FKIP Universitas Pattimura, abrahamsoyem@yahoo.co.id \\ ${ }^{4}$ FPendidikan Bahasa Jerman, FKIP Universitas Pattimura, febriotitaley@ rocketmail.com \\ ${ }^{5}$ Pendidikan Bahasa Inggris, FKIP Universitas Pattimura, meyttyjp@yahoo.com
}

\begin{abstract}
Abstrak: Provinsi Maluku memiliki potensi pariwisata yang sangat besar. Potensi pariwisata ini tersebar luas di seluruh kawasan Maluku bahakan sampai di pelosok-pelosok yang paling terpencil sekalipun. Kurang lebih terdapat sekitar 600 objek wisata di Maluku yang telah teridentifikasi. Potensi pariwisata yang demikian menjanjikan ini perlu didukung dengan ketersediaan tenaga pramuwisata yang handal. Kegiatan PKM ini memiliki dampak yang sangat positif terhadap 31 orang guide pemula. Para pemandu wisata yang tergabung dalam Himpunan Pramuwisata Indonesia-Maluku (HPI Maluku periode 2011-2015) telah merasakan manfaat dari kegiatan ini. Kegiatan ini terlaksana atas kerjasama dosen Jurusan Pendidikan Bahasa FKIP Universitas Pattimura dan Dewan Pimpinan Daerah HPI Maluku. Pengetahuan dan ketrampilan peserta seputar kepariwisataan secara umum dan kepemanduan secara khusus telah dikembangkan lewat kegiatan ini. Salah satu indikator manfaat yang dirasakan oleh mitra program ini adalah peningkatan profesionalitas dan ketrampilan berbahasa yang sangat diperlukan dalam kegiatan kepemanduan. Evaluasi yang dilakukan menunjukan adanya peningkatan kemampuan para tourist guide muda dalam aspek skill, teknik dan kepercayaan diri. Nilai tambah lain yang nyata adalah semakin erat ikatan persaudaraan antara sesama anggota HPI Maluku yang berbeda latar belakang suku dan agama yang diharapkan juga berdampak pada penciptaan kehidupan yang harmonis dalam masyarakat yang bhineka.
\end{abstract}

Kata Kunci: Maluku, pariwisata, pelatihan, kepemanduan.

Abstract: Maluku Province has a wealthy tourism potential. This tourism beauty is astonishingly scattered throughout the erchipelago, even up to the most remote and isolated places. There are more than 600 tourist objects in the province that have been identified, yet many more await to be explored. This promising resources need to be supported with the availability of qualified human resources in tourism sector. This present article reveals a result of a capacity building training upon 31 junior tourist guides in Maluku Province. The participants are member of Indonesia Tourist Guide Association (HPI Maluku, period 20112015). This community service program is realized through the collaboration between lecturers of Language and Art Department, Teachers Training Faculty of Pattimura University, and Maluku Tourist Guide Association. The participants improved their knowledge on tourism and tour guiding in particular. One of the indicators is professionalism and language skill which is pivotal in handling tourism-related activities. Novice guides benefitted hugely from this capacity building training in many aspects such as skill, technique and self-confidence. Additionally, another venue for creating harmonious peaceful life in multi-culture society is established through this occasion.

Keywords: Maluku, tourism, capacity building, tour guiding.

\section{PENDAHULUAN}

Sebagai bagian yang tak terpisahkan dari kegiatan usaha pariwisata, sudah bukan hal yang baru bahwa tenaga pramuwisata merupakan ujung tombak kepariwisataan di suatu wilayah atau negara. Hal ini karena kepemanduan bukan saja sebatas memberikan informasi yang benar tetapi juga memberikan pengalaman ekstraordinari kepada wisatawan lewat pelayanan yang diberikan [Guiding is not only about giving exact information, but also creating extraordinary experiences in the way service being provided"]. Di Provinsi Maluku ketersediaan tenaga lapangan untuk mengakomodir kebutuhan para wisatawan masih sangat terbatas. Apalagi kebutuhan akan tenaga pemandu lokal yang bertaraf internasional. Keahlian, kehandalan dan ketrampilan para pemandu 
wisata sangat berpengaruh dalam kemajuan kepariwisataan di Provinsi Maluku. Dikatakan sangat berpengaruh karena dari para pramuwisatalah informasi bagi para wisatawan bisa diberikan dan impresi terhadap kehidupan sosio-kultural di Maluku dapat dibawa pulang oleh para wisatawan ke daerah asal mereka. Lebih jauh, peran seorang pemandu wisata secara tidak langsung memiliki pengaruh yang besar bagi kemajuan perekonomian suatu daerah atau wilayah.

Dengan demikian, tenaga pemandu wisata haruslah dilengkapi dengan pengetahuan teoritis dan praktis seputar pelayanan kepramuwisataan. Menyediakan tenaga kepemanduwisataan yang handal tidak hanya bisa bergantung pada bakat alam tiap orang untuk menjadi tenaga pemandu wisata. Sebaliknya profesionalisme tenaga kepramuwisataan hanya bisa dicapai melalui kegiatan pendidikan dan pelatihan yang terpadu dan berkelanjutan. Upaya peningkatan kapasitas tersebut telah ditetapkan dalam program kerja DPD HPI Maluku periode 2011-2015. Diharapkan melalui program ini, potensi pariwisata Maluku dapat diimbangi dengan ketersediaan tenaga pramuwisata yang handal dan profesional. Anggota HPI Maluku terdiri dari para anggota yang berada pada tiga tingkatan yang berbeda yaitu senior, madya, dan muda. Semua anggota HPI Maluku wajib memiliki empat komponen keahlian penunjang kegiatan kepemanduwisataan yaitu pengetahuan (knowledge), ketrampilan (skill), sikap (attitude) dan bahasa (language) untuk dapat melaksanakan fungsi dan tugas secara optimal dan professional di lapangan.

Keterlibatan semua unsur masyarakat dalam penciptaan iklim pariwisata yang kondusif sangatlah penting. Namun di banyak kasus, seperti yang dikatakan oleh Sofield (2003) perhatian untuk pemberdayaan dan keberlangsungan usaha pariwisata kurang mendapat perhatian khususnya di negara-negara yang sedang berkembang. Begitupun perhatian terhadap tenaga pemandu wisata di Maluku, sangat kurang dari pihak pemerintah daerah ataupun instansi-instansi yang bertanggung-jawab dalam kegiatan usaha pariwisata. Melihat betapa pentingnya peranan pemandu wisata dalam menggerakan perekonomian masyarakat dan bangsa, maka para akademisi yang memiliki kompetensi dalam bidang pariwisata merasa perlu untuk melakukan suatu kegiatan pengembangan sumber daya manusia lewat kegiatan peningkatan kapasitas bagi praktisi kepemanduan di Maluku.

Hal ini dianggap penting karena tuntutan serta prasyarat menjadi tenaga pemandu wisata bukan hanya sebatas memiliki kemampuan berbahasa asing tertentu. Bukan pula sebatas kemampuan mengenali objek wisata dan geografi wilayah tertentu. Untuk menggeluti profesi pramuwisata, terdapat suatu kompleksitas tugas yang tidak bias dipandang sebelah mata atau dianggap remeh. Dengan mempertimbangkan hal tersebut maka disepakatilah suatu bentuk kerjasama antara DPD HPI Maluku dan para dosen pada Jurusan Pendidikan Bahasa dan Seni FKIP Unpatti untuk mengadakan program pengembangan dan pelatihan bagi 31 orang tour guide yang merupakan anggota HPI maluku.

\section{KAJIAN PUSTAKA}

Kegiatan manusia dalam kaitannya dengan wisata dilandaskan pada motivasi utama yakni untuk mencari kesenangan diri, memanjakan diri dengan mendapatkan kepuasan jasmani maupun spiritual lewat perjalanan-perjalanan ke wilayah-wilayah baru yang berbeda dengan daerah asal atau tempat tinggalnya. Wilayah-wiayah baru ini dinggap memiliki keindahan alam atau daya tarik lainnya yang tidak tersedia di dearah asal atau tempat tinggalnya. Ada tiga jenis tourism yang dikemukakan oleh Walker dan Harding (2006) yang salah satunya adalah leisure tourism yang meliputi setiap aktifitas yang dilakukan dalam waktu senggang yang bisa mendatangkan kesenangan atau sukacita bagi diri seseorang. Untuk memberikan kesenangan ini kepada wisatawan jelaslah bahwa daerah tujuan wisata harus bisa menunjang pemenuhan keinginan wisatwan tersebut.

Sarana produk kepariwisataan adalah semua bentuk usaha (barang atau jasa) yang dapat memberikan pelayanan kepada wisatawan. Misalnya: a. di bidang usaha jasa pariwisata, seperti: biro perjalanan wisata, agen perjalanan wisata, pramuwisata, konvensi, perjalanan intensif dan 
pameran, konsultan pariwisata, informasi pariwisata, b. di bidang usaha sarana pariwisata yang terdiri dari: akomondasi, rumah makan, bar, angkutan wisata dan sebagainya.

Potensi pariwisata mutlak harus didukung dengan berbagai infrastruktur penunjang pariwisata serta ketersediaan tenaga pramuwisata yang berkualitas dan profesional. Menurut Undang-undang no. 10 tahun 2009 tentang kepariwisataan, pariwisata adalah "berbagai macam kegiatan wisata yang didukung dengan ketersediaan fasilitas serta layanan dari masyarakat, pemerintah, pemerintah daerah dan pengusaha setempat, yang diberikan kepada wisatawan." Pengertian pariwisata menurut Damanik dan Weber (2006), parwisata adalah perpindahan orang untuk sementara dan dalam jangka waktu pendek ke tujuan-tujuan diluar tempat dimana mereka biasa hidup dan bekerja dan juga kegiatan-kegiatan mereka selama tinggal di suatu tempat tujuan.

Banyak negara di dunia telah membuktikan bahwa sektor pariwisata telah mendatangkan keuntungan yang sangat besar dalam menunjnag perekonomian masyarakatnya. Ketahanan ekonomi dapat tercapai dengan pengelolaan sumberdaya pariwisata yang profesional. Jika dilihat secara seksama, sebenarnya tidak semua dari negara-negara yang sektor pariwisatanya unggul memiliki objek wisata atau daerah wisata yang indah untuk dikunjungi. Tetapi pertanyaannya, mengapa negara-negara ini sangat sering dikunjungi. Tentu saja banyak faktor yang melatarbelakangi hal tersebut. Mulai dari faktor kenyamanan, keamanan, sampai dengan penanganan para turis oleh para pemandu lokal. Ketersediaan sarana dan prasarana penunjang seringkali menjadi penyebab kurangnya minat turis asing untuk mengunjugi Indonesia yang diperparah lagi dengan tingkah pola para tenaga pramuwisata yang jauh dari sikap dan pelayanan profesional.

Selain infrastruktur, pendidikan juga menjadi halangan. Meskipun di Pulau Bali dan hotelhotel mewah di Jakarta misalnya, kebanyakan penduduk asli yang bekerja di sektor pariwisata cukup fasih berbahasa Inggris (dan bahkan bahasa-bahasa asing lainnya), di wilayah-wilayah yang lebih terpencil penduduk asli kesulitan untuk berkomunikasi dengan para turis, sebagaimana dapat kita lihat di daerah-daerah di Provinsi Maluku. Oleh karena itu, fokus pada mempelajari Bahasa Inggris, paling tidak akan bisa membantu mengatasi keadaan ini. Sebagai contoh, halangan bahasa ini adalah alasan mengapa sejumlah warga Singapura lebih memilih Malaysia ketimbang Indonesia sebagai tempat tujuan wisata mereka. Kebanyakan turis asing yang datang ke Indonesia berasal dari Singapura, diikuti oleh Malaysia dan Australia.

Tabel 1. Kunjungan Wisatawan Asing di Indonesia, 2007-2015:

$\begin{array}{lccccccccc} & \mathbf{2 0 0 7} & \mathbf{2 0 0 8} & \mathbf{2 0 0 9} & \mathbf{2 0 1 0} & \mathbf{2 0 1 1} & \mathbf{2 0 1 2} & \mathbf{2 0 1 3} & \mathbf{2 0 1 4} & \mathbf{2 0 1 5} \\ \begin{array}{l}\text { Wisatawan Asing } \\ \text { (dalam juta) }\end{array} & 5.51 & 6.23 & 6.32 & 7.00 & 7.65 & 8.04 & 8.80 & 9.44 & 9.73\end{array}$

Sumber: BPS

Untuk mengatasi kesenjangan ini tidak ada jalan lain selain meningkatkan kerjasama dan koordinasi antar berbagai pihak untuk menyediakan fasilitas penunjang dan penyediaan sumber daya manusia yang berkualitas. Sebagaimana yang telah dibahas sebelumnya, tenaga pramuwisata harus dikembangkan dan dimatangkan. Tingkat keprofesionalan mereka dalam bidang kepemanduan harus terus ditingkatkan lewat pelatihan, workshop atau penyegaranpenyegaran [refresfhing] keilmuan dan ketrampilan harus terus digalakkan secara berkelanjutan. Nikijuluw (2014) menambahkan, selain memiliki kemampuan dan ketrampilan kepemanduan, seorang tenaga pramuwisata harus cakap dalam menjalin dan membina hubungan yang harmonis dengan masyarakat. Ia juga harus punya wawasan terhadap industri-industri lokal yang dikembangkan oleh masyarakat untuk dikonsumsi atau yang akan dibeli oleh wisatawan ketika mereka berkunjung ke suatu wilayah. 


\section{METODE}

Kegiatan peningkatan kapasitas (Capacity Building) bagi pemandu wisata di Maluku dilaksanakan dengan pendekatan pembelajaran di dalam kelas (indoor) dan di luar kelas (outdoor). Hal ini disesuaikan dengan kebutuhan dan nature dari materi pelatihan dan pelaksanaannya. Dikarenakan kepakaran yang berbeda maka kegiatan pelatihan dan pengembangan ini mempertimbangkan pendistribusian dan pembagian tugas dengan konsep task sharing. Pembagian tugas berdasarkan ranah kepakaran dan pengalaman dari masing-masing institusi dan individu fasilitator. Pihak akademisi yang memiliki kepakaran dalam ketrampilan berbahasa Inggris dan Jerman membekali para peserta dengan ketrampilan bahasa Inggris dan Jerman yang diperlukan dalam bidang kepariwisataan dan kepemanduan. Dua orang dosen dengan kepakaran dalam bidang Bahasa Inggris berkolaborasi dengan seorang dosen yang memiliki kepakaran dalam bidang Bahasa Jerman. Beberapa tenaga ahli (senior guides) disiapkan oleh DPD HPI Maluku berdasarakan kepakarannya. Dalam kegiatan pelatihan ini, para pakar ini memberikan materi dan workshop dalam berbagai aspek antara lain etiquette, pengetahuan budaya, pemahaman geografi, dan sebagainya.

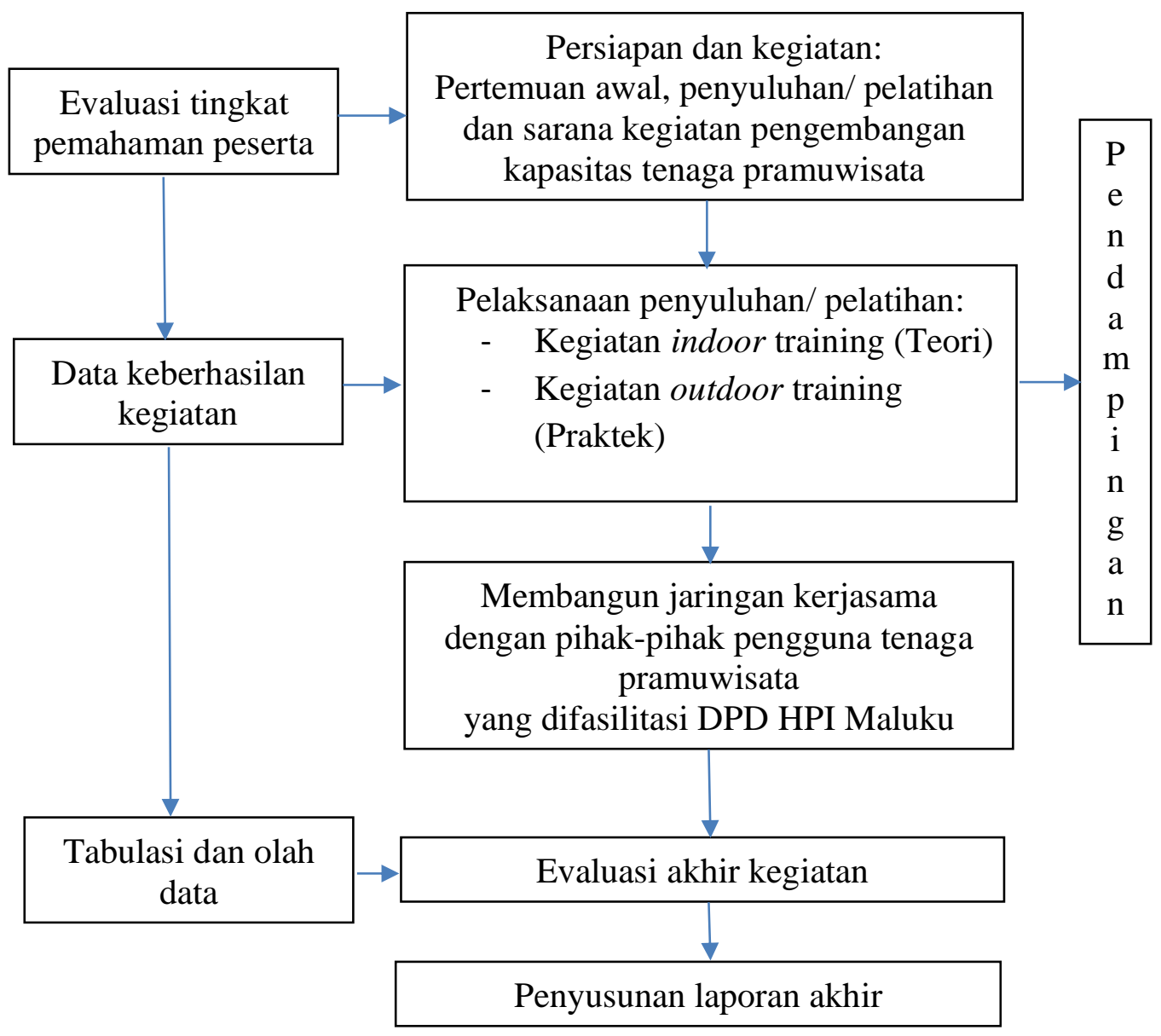

Bagan 1. Bagan alir pelaksanaan kegiatan Capacity building bagi pemandu wisata Maluku. 
Sebelum kegiatan pelatihan dilaksanakan, terlebih dahulu dilakukan pertemuan awal antara para narasumber atau fasilitator yang diprakarsai oleh tim penulis. Dalam pertemuan ini dibahas mekanisme pelatihan dan penjadwalan dan penentuan kelas dan fasilitatornya. Dengan masukan yang diberikan oleh semua pihak yang terlibat dalam pertemuan awal, maka disepakati materimateri pelatihan. Penetapan materi ini juga mempertimbangkan situasi dan kondisi para peserta yang terlibat dalam kegiatan ini. Needs assessment awal dilakukan dengan cara menyebarkan angket ke peserta. Dengan demikian penyampaian materi dan pelatihan bisa sesuai dengan kebutuhan mereka. Agar pelatihan ini efektif diputuskan bahwa kegiatan ini harus dilakukan dalam beberapa tahapan dalam beberapa kali pertemuan. Metode yang digunakan dalam kegiatan pengabdian ini adalah pemberian pembekalan teoritis dan kegiatan praktis kepemanduan. Peserta pelatihan dibekali dengan ketrampilan teoritis tentang kepemandu-wisataan melalui indoor workshop dan outdoor practice (praktek lapangan). Keseluruhan metode pelaksanaan kegiatan peningkatan kapasitas tenaga pemandu wisata yang tergabung di dalam HPI Maluku dapat dilihat dalam bagan alur kegiatan [Gambar 1].

Dalam pelaksanaan kegiatan pengabdian ini tim dosen pengusung melibatkan beberapa orang mahasiswa tingkat akhir guna melancarkan kegiatan pengabdian ini sekaligus sebagai wadah pengaplikasian pemahaman teoritis para mahasiswa tersebut. Bentuk nyata keterlibatan mahasiswa sekaligus wahana penerapan ilmu pengetahuan yang mereka dapatkan selama perkuliahan adalah dengan ikut serta memberikan materi seputar ketrampilan berbahasa Inggris dan Bahasa Jerman kepada para peserta pelatihan peningkatan kapasitas tenaga pramuwisata. Fasilitator dijadwalkan secara bergiliran untuk memberikan materi pada ketiga kelas tersebut sehingga semua peserta pelatihan memperoleh porsi pelatihan dan materi yang seragam. Masingmasing kelompok belajar dikoordinir oleh masing-masing instruktur yang bertanggung jawab terhadap kelas dan peserta belajar masing-masing.

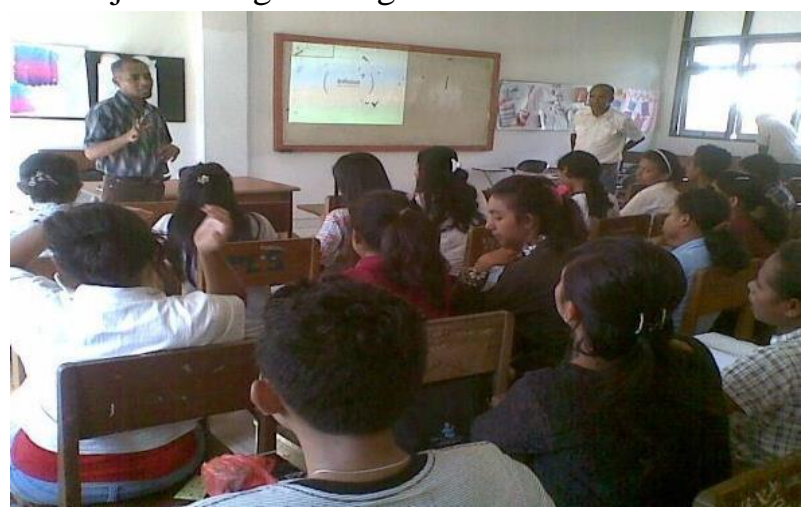

Gambar 1. Pembelajaran dalam kelas (Indoor).

Efektifitas dan efisiensi menjadi pertimbangan utama dalam pelaksanaan program peningkatan kapasitas ini. Kegiatan belajar dilakukan dengan menggunakan berbagai pendekatan sehingga pembelajaran tidak monoton dan membosankan. Model ceramah dibarengi dengan kegiatan diskusi, simulasi dan kerja kelompok merupakan bentuk kegiatan pembelajaran tersebut. Para peserta sering juga terlibat dalam kegiatan role play atau bermain peran untuk memantapkan pemahaman materi yang disampaikan oleh para fasilitator. Para fasilitator sendiri merupakan tenaga relawan yang notabene adalah para tour guide senior yang tergabung dalam HPI Maluku maupun yang memiliki afiliasi tersendiri atau dengan institusi lain. Peserta pelatihan dibagi menjadi tiga kelompok belajar dengan menggunakan modul pelatihan yang sama.

Dalam pelaksanaan kegiatan pengabdian ini, tim pengusung berkoordinasi dengan pihakpihak yang memiliki keterkaitan dengan pelayanan kepariwisataan. Sebagai contoh, pihak pengelola bandara International Pattimura Ambon membantu tim dalam sesi pelatihan seputar pelayanan transfer service. Pengenalan tentang pelayanan yang diberikan kepada para turis dalam materi "transfer in" dan "transfer out" yang diperoleh di kelas diperkuat dengan penjelasan dan pengamatan aktual di lapangan, terlebih khusus persoalan penanganan dokumen dan barang yang dibawa oleh turis. Para peserta pelatihan diperkenalkan dengan sistem dan prosedur yang harus 
dilakukan pada saat menjemput tamu atau turis. Petugas pengelola bandara juga memberikan pengarahan dan penjelasan kepada peserta tentang segala hal yang perlu diketahui oleh para pemandu. Selain dengan pihak pengelola Bandara Internasional Pattimura, tim juga berkoordinasi dengan pengelola pelabuhan laut Yos Sudarso untuk melakukan kegiatan praktek pelayanan penjemputan tamu/turis di pelabuhan laut.

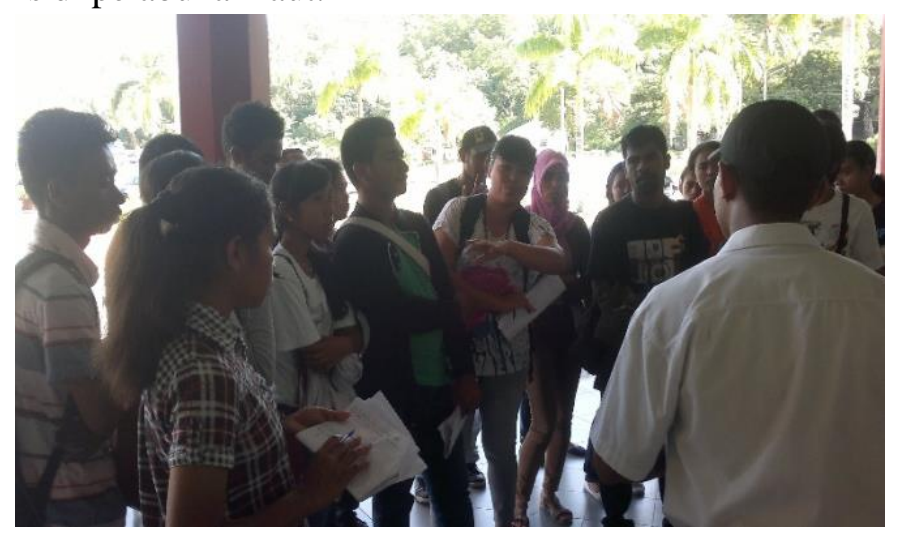

Gambar 2. Praktek Outdoor, bentuk pelayanan Transfer service

\section{HASIL DAN PEMBAHASAN}

\section{Perspektif baru bagi Pramuwisata pemula}

Sebagaimana sasaran dari kegiatan pengabdian ini, para peserta telah memperoleh pengetahuan dan ketrampilan kepemanduan-wisata. Peningkatan ketrampilan bahasa asing (Jerman dan Inggris) yang berkaitan dengan kepemanduwisataan telah diperoleh para peserta walau hasilnya belum bisa dikatakan sangat memuaskan, dan masih perlu ditingkatkan lewat kegiatan pelatihan dan pengembangan lanjutan. Dari hasil evaluasi kegiatan, terlihat bahwa hampir semua peserta mengalami peningkatan dalam keempat aspek kemampuan yang diajarkan yaitu ketrampilan (skill), sikap (attitude), pengetahuan (knowledge), dan bahasa (language). Peserta pelatihan yang sebagian besar adalah tour guide pemula dan madya menyatakan bahwa keterlibatan mereka dalam kegiatan ini telah memberikan mereka perspektif yang baru.

Kesadaran terhadap profesionalisme selaku tenaga kepramuwisataan dalam memberikan pelayanan kepramuwisataan semakin meningkat. Sebagai contoh dalam pemberian materi tentang etiquette peserta diajarkan untuk tidak boleh 'menjual' negara dalam artian tidak boleh menjelek-jelekan negara sendiri dengan alasan apapun. Walaupun dianggap hanya untuk berbasa-basi atau bersenda-gurau dengan wisatawan. Pramuwisata tidak boleh menceritakan perihal pribadi kepada wisatawan. Peserta diberi contoh kasus, ada pramuwisata menceritakan keadaan anggota keluarga (istri, anak, orang-tua) yang sakit parah dan membutuhkan biaya untuk pengobatan atau operasi. Ternyata, masih ada pramuwisata yang menganggap hal ini lumrah. Setelah mendapat pengarahan dan pembelajaran terkait etos kerja dan etik dalam kegiatan pemanduan, para peserta memahami bahwa hal itu sangat dilarang keras.

Dari segi kemampuan berbahasa, peserta dievaluasi lewat kegiatan praktek agar lebih praktis dan lebih mempertimbangkan biaya, keperluan logistik dan administratif lainnya yang tidak terlalu diperlukan dalam mencapai tujuan kegiatan ini. Peserta yang telah dibekali dengan aspek-aspek ilmu kebahasaan praktis dalam kepemanduan dapat mengaplikaikannya dalam praktek. Mereka bisa menjelaskan objek-objek wisata dengan menggunakan bahasa Inggris maupun Jerman dengan cukup baik. Yang menarik mereka mengatakan bahwa kepercayaan diri mereka meningkat dalam menggunakan bahasa asing untuk memandu wisatawan. 


\section{Peningkatan Ketrampilan yang berorientasi pada profesionalisme}

Salah satu luaran dari hasil kegiatan ini adalah pemberian sertifikat kompetensi yang diberikan kepada peserta kegiatan peningkatan kapasitas tenaga pramuwisata. Pemberian sertifikat ini menandakan bahwa peserta yang terlibat telah memenuhi kompetensi yang diperlukan untuk menjadi pramuwisata. Namun untuk dikategorikan sebagai pramuwisata professional bertaraf nasional, para peserta selanjutnya harus mengikuti tes kelayakan yang dilakukan oleh Badan Nasional Akreditasi Profesi Pramuwisata Nasional. Kegiatan yang dilakukan saat ini diharapkan mampu memberikan pengetahuan dan ketrampilan bagi para pramuwisata Maluku untuk mengikuti akreditasi.

Lewat kegiatan ini telah nyata bahwa para peserta sudah boleh dikatakan berkompetensi dalam aspek ketrampilan (skill), kompetensi sikap (attitude), kompetensi pengetahuan (knowledge), dan kompetensi bahasa (language). Lewat kegiatan-kegiatan diskusi, para peserta telah mendapat perluasan wawasan pengetahuan dimana banyak hal yang tidak diketahui sebelumnya menjadi jelas setelah ada masukan dari fasilitator maupun peer. Sebagai contoh, peserta diajarkan untuk bisa bersikap cerdas, cerdik dan tactful dalam menjawab atau merespon pertanyaan-pertanyaan yang mungkin timbul dari para wisatawan yang dipandunya. Berterus terang dengan cara yang elegan adalah lebih baik daripada berlagak tahu tetapi memberikan jawaban yang konyol. Peserta diingatkan bahwa para wisatawan biasanya adalah orang-orang yang terdidik yang tidak bisa dibohongi dengan informasi-informasi yang salah dari pramuwisata. Lebih baik berkata, "saat ini saya belum bisa memberikan jawaban atas pertanyaan tersebut karena saya sendiri belum mengetahuinya, tetapi saya berjanji akan segera memberitahu anda sesegera mungkin setelah mengetahuinya" daripada berbohong.

Selain itu telah dihasilkan sebuah modul sebagai suatu pedoman praktis bagi para pemandu yang tergabung dalam HPI Maluku. Kegiatan ini telah mendapat respon yang positif dari mitra penerima aplikasi kegiatan ini. Dewan pengurus dan Anggota HPI Maluku sangat merasakan manfaat dari kegiatan ini. Selain penguatan kapasitas anggota yang ada, banyak juga anggota baru yang telah bergabung dengan HPI karena termotivasi lewat kegiatan ini. Mereka menyadari bahwa tidaklah cukup memilik 'bakat alam' dalam melakukan operasi kepemanduan wisata. Tidak hanya itu, kesempatan berkarya dan bekerja lebih terbuka lebar bagi para generasi muda yang tergabung dalam organisasi profesi ini. Mengingat kegiatan pelatihan ini untuk meningkatkan ketrampilan dan pengetahuan para pemandu wisata dalam bidang kepemanduan, Sebelum kegiatan peningkatan kapasitas ini, rata-rata peserta dikategorikan memiliki pengetahuan kepemanduwisataan yang rendah. Tingkat ketrampilan berbahasa, baik bahasa Inggris maupun bahasa Jerman, berada pada tingkatan "Low intermediate" bahkan ada sebagian yang tingkat ketrampilan berbahasanya berada pada tingkat "Basic" bahkan dikategorikan "Poor." Selain kegiatan belajar mengajar di dalam kelas (indoor activities), peserta pelatihan juga terlibat dalam kegiatan praktek memandu wisata di lapangan. Peserta dilatih bagaimana mengatur penjemputan (Transfer in), pengantaran (Transfer out) dan bagaimana cara memandu di atas kendaraaan (bis) yang sedang berjalan (on board guiding). Pengetahuan-pengetahuan praktis yang tidak terpikirkan sebelumnya oleh para peserta kini semakin diperkaya. Misalnya bagaimana cara memegang microphone yang benar saat melakukan pemanduan dalam bis yang sementara bergerak, dsb. Mempromosikan kehidupan harmonis antar para anggota HPI Maluku yang berbeda latar belakang suku, ras dan agama telah membuka jalan yang lebih luas untuk penciptaan kehidupan harmonis bagi masyarakat. Para peserta semakin menumbuhkan rasa saling memahami atas perbedaan yang ada, dan menganggap perbedaan itu sebagai khasanah kekayaan nusantara yang berpotensi mendatangkan manfaat bagi dunia pariwisata. 


\section{TEMUAN ATAU DISKUSI}

Setelah dievaluasi dan dilakukan refleksi, kegiatan ini terbukti membawa manfaat positif bagi para peserta yang terlibat dalam program kegiatan peningkatan kapasitas tenaga pramuwisata. Materi yang disampaikan oleh para pemateri sangat integratif dan inklusif. Materi-materi yang berkaitan langsung dengan kemampuan kepemanduwisataan diselingi juga dengan nilai-nilai kebersihan, tenggang rasa dan pembangunan karakter. Mengingat keberagaman anggota HPI, melalui kegiatan ini telah terbina suatu ikatan kekerabatan yang lebih erat antar para anggota yang berbeda latar belakang suku dan agama. Kabar menggembirakan dari kegiatan ini adalah, semakin banyak tenaga pramuwisata yang dipekerjakan oleh agen-agen perjalanan wisata di kota Ambon maupun di daerah sekitarnya.

Selain sasaran dan tujuan khusus dari kegiatan ini yang telah disebutkan sebelumnya, kegiatan pengabdian ini telah memberikan nilai tambah bagi peserta dimana mereka semakin merasa bertanggung-jawab dalam menjaga kebersihan lingkungan. Kesadaran untuk menjunjung pola hidup bersih dan sehat bagi terciptanya kenyamanan bagi wisatawan sangatlah penting. Dalam pelaksanaan setiap kegiatan, para peserta seringkali dimotivasi untuk menjalankan perilaku hidup bersih. Sebagai contoh, para peserta diwajibkan menjaga dan memelihara ketertiban dan kebersihan ruangan kelas dan daerah sekitarnya. Mereka diarahkan untuk menjadi agen-agen perubahan dan agen-agen kebersihan di lingkungan mereka masing-masing. Para peserta juga terlibat aktif membantu pemerintah daerah menjalankan program kebersihan dengan melakukan kerja bakti pada lokasi-lokasi wisata dan tempat-tempat umum. Para anggota HPI terlibat dalam program pemerintah kota Ambon "Jumpa Berlian" (Jumat Pagi Bersihkan Lingkungan).

Lebih jauh dengan memperhatikan prinsip keberlangsungan (sustainability) tim pengusung juga memberikan penguatan kepada para anggota maupun perangkat pengurus HPI Maluku untuk tetap bersinergi dalam menjalankan setiap kegiatan yang bersifat pengembangan sumberdaya manusia. Dalam kegiatan pengabdian inipun, tim pengusung sengaja melakukan pendampingan kepada peserta dalam mengatur setiap program kerja. Bagi peserta pelatihan yang dianggap mampu, langsung dipromosikan menjadi tenaga pemandu pada biro-biro perjalanan wisata. Hal ini tentu saja setelah tim pengusung berkoordinasi dengan para pemilik biro perjalanan wisata. Sistim koordinasi terstruktur ini sengaja ditularkan kepada para peserta pelatihan sehingga mereka dapat melihat manfaat ketertiban organisasi dan keterkaitan langsung antara pelatihan dan kesempatan berkarya dalam dunia pariwisata.

\section{SIMPULAN DAN SARAN}

Kegiatan pengembangan sumber daya manusia yang dalam hal ini dilakukan untuk meningkatkan profesionalisme para tour guide lokal di Kota Ambon dan sekitarnya merupakan suatu usaha kecil yang memiliki spektrum yang cukup luas. Hal ini perlu mendapat dukungan dari pihak pemerintah dan instansi-instansi terkait lainnya. Tampak jelas dari kegiatan ini bahwa kita masih membutuhkan banyak sarana dan fasilitas pendukung pariwisata. Di sisi lain, peningkatan kemampuan kepemanduan wisata bagi masyarakat yang menekuni usaha jasa pariwisata dan kepemanduan masih belum mendapat perhatian serius baik dari pemerintah lokal maupun pemerintah pusat. Terkesan bahwa usaha peningkatan kapasitas tenaga pramuwisata masih bersifat discrete dan kurang menekankan koordinasi antar institusi, masing-masing cenderung berjalan sendiri-sendiri.

Program semacam ini telah memperlihatkan hasil yang cukup memuaskan walau belum bisa dikatakan sempurna. Paling tidak peserta program ini merasakan adanya peningkatan pemahaman terhadap aspek-aspek pelayanan kepariwisataan. Ketrampilan praktis seputar penguasaan bahasa asing dan ketrampilan dasar memandu wisatawan sudah dikuasai sehingga menghindarkan mereka dari perilaku-perilaku yang tidak profesional ketika memandu suatu tour. Diharapakan kegiatan seperti ini dapat dikembangkan di masa-masa mendatang dengan melibatkan lebih 
banyak lagi peserta dan konteks yang lebih luas, misalnya pada kota/kabupaten lain di Maluku maupun luar Maluku.

Generasi berganti. Saat ini banyak dari pemandu wisata senior di Maluku sudah memasuki usia purnabakti dan ada yang telah fokus pada profesi utama sebagai dosen, guru, dan pegawai sipil. Otomatis keterlibatan mereka secara langsung dalam dunia kepemanduan sudah sangat terbatas. Kekuatan sektor pariwisata di Maluku, terkhusus tenaga pramuwisata perlu dipetakan kembali untuk mendapatkan gambaran pasti ketersediaan tenaga pramuwisata yang profesional. Hal ini membutuhkan kerjasama dan koordinasi yang baik antara DPD HPI Maluku dan instansi terkait lainnya, khususnya Dinas Pariwisata Propinsi. Para akademisi yang memiliki kepakaran dalam kaitannya dengan sektor usaha pariwisata juga harus jeli melihat tantangan yang ada saat ini dan berkontribusi aktif dalam membantu masyarakat menghadapi tantangan dalam dunia pariwisata.

\section{DAFTAR RUJUKAN}

[1] Badan Pusat Statistik. (2018). Statistik Indonesia; Statistical Year Book of Indonesia 2018.

[2] Cole, S. (2011). Information and empowerment: the keys to achieving sustainable tourism. Journal of Sustainable Tourism, 14:6, 629-644, DOI: 10.2167/jost607.0

[3] Damanik, Janianton, \& Weber, Helmut. (2006) Perencanaan Ekowisata: Dari Teori ke Aplikasi. Yogyakarta. PUSPAR UGM dan Andi.

[4] Walker, R. \& Hasting, K. (2006). Oxford English for careers. Tourism. Teacher's resource book. Oxford University Press: New York.

[5] Sofield, T. (2003). Empowerment for Sustainable Tourism Development. Oxford: Pergamon.

[6] Sulastiyono, A. (2011). Manajemen Penyelenggaraan Hotel. Seri Manajemen Usaha Jasa Sarana Pariwisata, Alfabeta, Bandung.

[7] ---. (2009). Undang-undang No. 10 tahun 2009 Tentang Kepariwisataan. Indonesia. 